\title{
MAPK3 wt Allele
}

National Cancer Institute

\section{Source}

National Cancer Institute. MAPK3 wt Allele. NCI Thesaurus. Code C52875.

Human MAPK3 wild-type allele is located in the vicinity of $16 \mathrm{p} 11.2$ and is approximately 9 $\mathrm{kb}$ in length. This allele, which encodes mitogen-activated protein kinase 3 protein, plays a role in the regulation of various cellular processes such as proliferation, differentiation, and cell cycle progression in response to a variety of extracellular signals. 